\title{
An Investigation of Induced Voltages to an Underground Gas Pipeline from an Overhead Transmission Line
}

\author{
Hiroshi Isogai Student Member (Doshisha University, dtd0117@mail4.doshisha.ac.jp) \\ Akihiro Ametnai Member (Doshisha University, aametani@mail.doshisha.ac.jp) \\ Yuji Hosokawa Non-member (Tokyo Gas Co., yuji@tokyo-gas.co.jp)
}

Keywords: induced voltage, gas pipeline, overhead line, mutual impedance, EMTP

This paper investigates induced voltage characteristics to a buried gas pipeline from an overhead power line illustrated in Figure 1 based on a modeling method developed by the authors by using EMTP.

It is confirmed that EMTP simulation results for a single phase power line agree well with an well-known formula of an induced voltage. A voltage on a pipeline section with no parallel power line is nearly the same as that with a parallel power line. This fact follows an electrostatic theory.

Table 1 shows an EMTP simulation result for a vertical twincircuit power line. It is observed that the induced voltages depends significantly on the power line configuration, a 3-phase horizontal

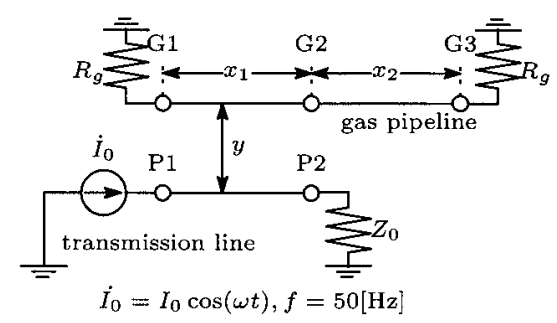

(a) A distributed-line model

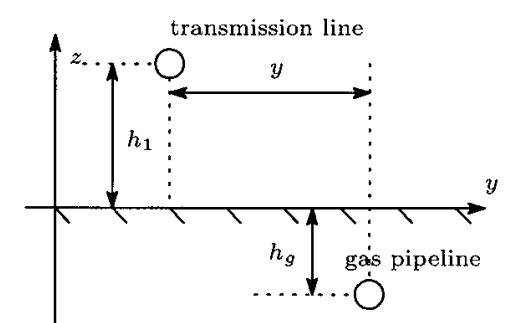

(b) A lumped-parameter model

Fig. 1. A model circuit of a power line and gas pipeline system line results in the highest induced voltage and that by a vertical twincircuit line is smaller by about $20 \%$ than that of a vertical singlecircuit line. The results are confirmed by hand calculations based on the well-known formula, and are readily explained by a vector sum of a magnetic flux around the pipeline.

Figure 2 shows a simulation result corresponding to a measured result in an actual gas pipeline with the total length of about $20 \mathrm{~km}$ partially parallel to $66 \mathrm{kV}$ and $500 \mathrm{kV}$ power lines. The simulation result agrees satisfactory with the measured result, $1.76 \mathrm{~V}$ to $2.48 \mathrm{~V}$, and thus the accuracy of the modeling method is confirmed to be satisfactory.

Table 1. Simulation results on a multiphase line

\begin{tabular}{|c|c|l|l|l|}
\hline case & $y[\mathrm{~m}]$ & $V_{G 1} \angle \theta_{1}[\mathrm{~V}]$ & $V_{G 2} \angle \theta_{2}[\mathrm{~V}]$ & $V_{m} \angle \theta_{m}[\mathrm{~V}]$ \\
\hline 31 & -100.0 & $1.52 \angle-158.1^{\circ}$ & $1.29 \angle-155.8^{\circ}$ & $0.24 \angle 9.3^{\circ}$ \\
\hline 32 & -28.0 & $4.18 \angle-176.2^{\circ}$ & $4.22 \angle 3.95^{\circ}$ & $8.40 \angle 3.9^{\circ}$ \\
\hline 33 & -14.0 & $5.90 \angle-175.4^{\circ}$ & $7.30 \angle-2.55^{\circ}$ & $13.1 \angle 0.6^{\circ}$ \\
\hline 34 & 0.0 & $3.16 \angle 116.1^{\circ}$ & $3.07 \angle 118.6^{\circ}$ & $0.16 \angle-119.1^{\circ}$ \\
\hline 35 & 14.0 & $6.67 \angle 6.37^{\circ}$ & $6.55 \angle-171.4^{\circ}$ & $13.2 \angle-172.5^{\circ}$ \\
\hline 36 & 28.0 & $4.28 \angle 3.59^{\circ}$ & $4.18 \angle-175.3^{\circ}$ & $8.46 \angle-175.9^{\circ}$ \\
\hline 37 & 100.0 & $1.41 \angle 13.8^{\circ}$ & $1.17 \angle 21.2^{\circ}$ & $0.29 \angle 162.7^{\circ}$ \\
\hline
\end{tabular}

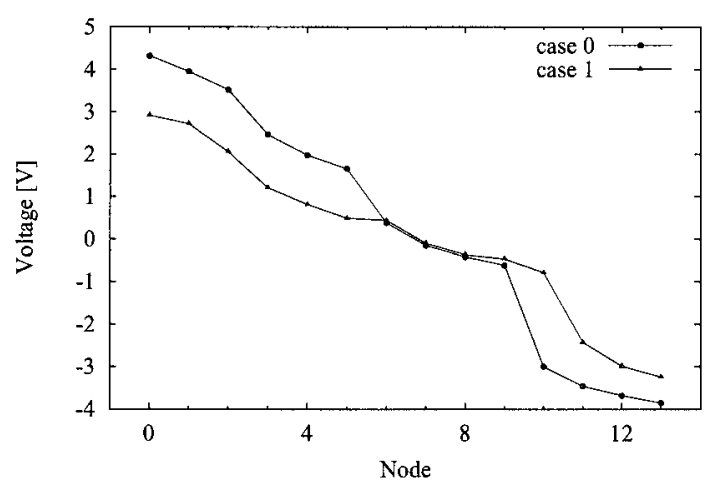

Fig. 2. Simulation results 


\title{
架空送電線から地中ガスパイプラインへの誘導電圧に関する一検討
}

\author{
学生員 磯貝 浩* 正 員 雨谷 昭弘* \\ 非会員 細川 裕司**
}

\section{An Investigation of Induced Voltages to an Underground Gas Pipeline from an Overhead Transmission Line}

Hiroshi Isogai*, Student Member, Akihiro Ametani*, Member, Yuji Hosokawa**, Non-member

This paper has investigated induced voltages characteristics from an overhead transmission line to a buried gas pipeline by applying a modeling method of the induced voltages proposed by the authors. EMTP simulation results agree with analytical results obtained from a well-known formula. The induced voltages are significantly dependent on the configuration of an overhead line. A horizontal line induces the largest voltage to the gas pipeline, and an induced voltage by a vertical twin-circuit line is smaller by about $20 \%$ than that by a vertical single-circuit line.

キーワード：誘導電圧，ガスパイプライン，架空線，相互インピーダンス， EMTP

Keywords: induced voltage, gas pipeline, overhead line, mutual impedance, EMTP

\section{1. 緒言}

地中に埋設されたガスパイプラインは，需要家へ供給す る経路として広く使用されている。ガスパイプラインの鋼 管塗覆装に損傷が生じた場合，損傷部からの電気腐食など によってガスパイプ本体に損傷を与え，大事故に至る危険 性がある(1)。この電気腐食の原因として，鉄道等による迷 走電流によるものと, 架空電力線からの交流誘導によるも のがある。前者については多くの研究が行われ, 外部電源 による電圧印加等の対策が講じられている。一方, 後者の ガスパイプへの交流誘導電圧については低接地措置等によ る対策が講じられているものの, 現象に関する検討が十分 なされておらず，その予測および特性の解明が求められて いる。また地中に埋設されたガスパイプラインの電圧測定 は困難であり, 誘導電圧シミュレーション手法の確立が急 務となっている。

そこで本論文ではガスパイプ交流誘導電圧の特性を明ら かにするため，まずシミュレーション手法を確立する。ガ スパイプラインは中空円筒状の導体部およびその外部の絶 縁体から成る地中ケーブルとして模擬することで，その数 值シミュレーションが可能となる ${ }^{(2)}$ 。その際，地中ケーブ

\footnotetext{
$*$ 同志社大学工学部

于610-0321 京田辺市多々羅

Faculty of Engineering, Doshisha University

Kyo-Tanabe, Kyoto 610-0321

** 東京ガス (株) 導管部

干 105-8527 東京都港区海岸 1-5-20

Dept. Pipeline, Tokyo Gas Co.

1-5-20, Kaigan, Minato-ku, Tokyo 105-8527
}

ルの定数は汎用回路解析プログラム $\mathrm{EMTP}^{(3)}$ のサブルー チンである Cable Parameters ${ }^{(4)}$ を用いることで容易に求ま る。また, 架空線と地中ケーブルの相互インピーダンスは Pollaczek $^{(5)}$ により厳密解が与えられているが, 無限積分を 含み数值的に極めて不安定である。一方, 大地の複素透過 深度 $h_{e}$ が地中ケーブル埋設深さよりも大となる条件下で は，その相互インピーダンスは Cable Parametersにより近 似計算が可能である ${ }^{(6)}$ 。

次に実測結果との比較等により開発したモデル回路の妥 当性およびシミュレーション精度について検討する。まず 架空電力線 1 条の最も基本的な構成について考察し, 3 相 水平配列線路, 3 相垂直配列線路および 3 相 2 回線路の場 合のガスパイプライン交流誘導電圧をそれぞれ比較する。 さらに実系統に対応するモデル系統を対象として，ガスパ イプ交流誘導電圧の予測を行う (7)(8)。

\section{2. 架空送電線およびガスパイプラインの分布定数 線路模擬}

ガスパイプラインの断面図を図 1 に示す。ガスパイプは 鋼管の周囲を塗覆装と呼ばれる保護体でコーティングされ ている。ここでガスパイプラインを電気素子と考えると, 中 空円筒状の導体部およびその外部絶縁体から成る地中ケー ブルとして模擬できる。本章では, ガスパイプラインを分 布定数線路として模擬する場合に必要なパラメータについ て検討し，モデル化手法を確立する。

〈2・1〉 ガスパイプラインの分布定数線路モデル分布 定数線路の性質を決定する特性インピーダンス $Z_{0}$, 伝搬定 数厂は次式で与えられる ${ }^{(9)}$ 。 


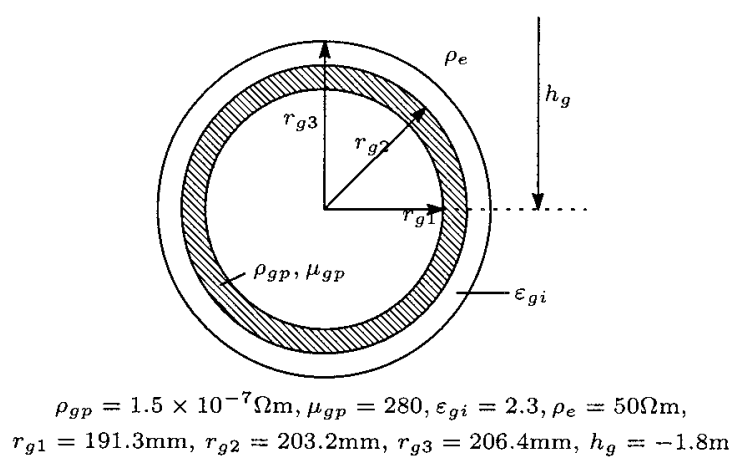

図 1 ガスパイプライン断面図

Fig. 1. Cross-section of a gas pipeline.

$$
\begin{aligned}
& Z_{0}=\sqrt{\frac{R+j \omega L}{G+j \omega C}} \ldots \ldots \ldots \ldots \\
& \Gamma=\sqrt{(R+j \omega L)(G+j \omega C)} .
\end{aligned}
$$

ここで直列インピーダンス $(R+j \omega L)$, および並列アドミタ ンス $(G+j \omega C)$ のキャパシタンス $C$ は EMTP のサブルー チンである Cable Parameters ${ }^{(4)}$ を用いて図 1 の物理定数よ り求められる。

また並列アドミタンス $(G+j \omega C)$ 中の $G$ を用いてガスパ イプライン塗覆装の漏れコンダクタンスを模擬できると考 えられる。ガスパイプラインの塗覆装にはピンホールなど からの大地への漏れ電流が存在することが知られており， 文献 (2) でも検討されている。ただしこの漏れコンダクタ ンスの值はガスパイプライン接地抵抗值に比べて非常に大 となっているのでほぼ絶縁されているとみなせる。

〈2・2〉架空電力線とガスパイプラインの相互インピー ダンス 図 2 に架空電力線とガスパイプラインの配置を 示す。なお, 電力線半径 $r_{p}=16.77 \mathrm{~cm}$ は $500 \mathrm{kV}$ 送電線の 1 相 4 導体（表 4 参照）の等価半径である。本節では図に 示す計算条件で架空電力線とガスパイプラインの相互イン ピーダンスについて検討する。架空線と地中ケーブルの相 互インピーダンスは Pollaczek ${ }^{(5)} に よ り$ 㛜密解が与えられて いるが，無限積分を含み数值的に極めて不安定である。一 方, 次式に示す大地の複素透過深度 $h_{e}$ が地中ケーブル埋設 深さよりも大となる条件下では, その相互インピーダンス は Cable Parameters により近似計算が可能である(6)。

$$
h_{e}=\sqrt{\frac{\rho_{e}}{j \omega \mu_{0}}}
$$

ガスパイプラインの埋設深さ $h_{g}$ が $h_{g}<\left|h_{e}\right|$ となるとき Cable Parameters を用いて相互インピーダンスを近似的に 求めることができる。ここで (3) 式に今回の計算条件 $\rho_{e}=$ $50[\Omega \mathrm{m}], h_{e}=h_{g}=1.8[\mathrm{~m}]$ を代入すると $f=1.95[\mathrm{MHz}]$ となる。よって Cable Parameters を用いて 1.95 [MHz] 以 下の周波数領域で計算可能である。

〈2·3〉架空線-ガスパイプラインのモデル回路 図 3 に架空線ーガスパイプラインのモデル回路を示す。(a) は分

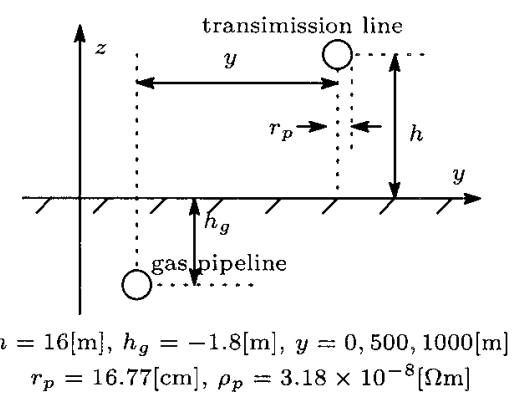

図 2 電力線・ガスパイプ系

Fig. 2. A power line and gas pipeline system.

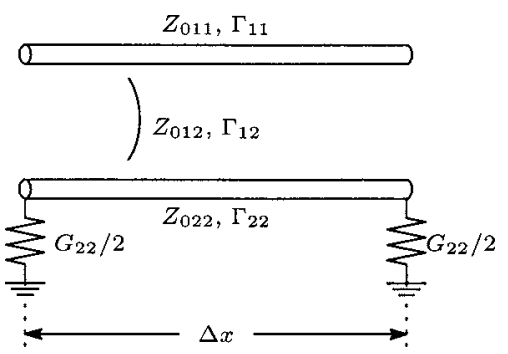

(a) A distributed-line model

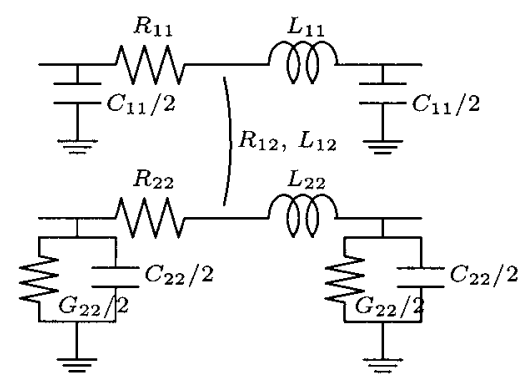

(b) A lumped-parameter model

図 3 電力線・ガスパイプライン系のモデル回路

Fig. 3. A model circuit of a power line and gas pipeline system.

布定数モデル，(b) は集中定数モデルである。眓において直 列インピーダンス行列 $[Z]$, 並列アドミタンス行列 $[Y]$, 特 性インピーダンス行列 $\left[Z_{0}\right]$, および伝搬定数行列 $[\Gamma]$ の各 定数は周波数の関数として EMTP Cable Parameters で計算 する。これらの定数を用いることにより架空線ーガスパイ プラインからなる多導体系を図 3 のモデル回路で表現する ことができる。

\section{3. ガスパイプへの交流誘導電圧}

〈3.1〉単相線路図 4(a)に検討対象としたシミュレー ション回路, 図 4(b) に断面図を示す。ノード G1-G2 区間 (距離 $x_{1}$ ) で $500 \mathrm{kV}$ 送電線 (単相模擬, 地上高 $h_{1}=16 \mathrm{~m}$ ) と地中ガスパイプ (埋設深さ $h_{g}=-1.8 \mathrm{~m}$ ) が離隔距離 $y$ で 平行している。ガスパイプラインの半径および物理定数は 図 1 と同じである。またノード G2-G3 区間（距離 $x_{2}$ ) はガ スパイプのみとし, 送電線始端 P1 に電流源 $I_{0}$ が接続されて いる時のガスパイプ端子電圧 $V_{G i}$ および送電線からの誘導 電圧 $\dot{V}_{m}=\dot{V}_{G 2}-\dot{V}_{G 1}$ を EMTP シミュレーションにより求め 


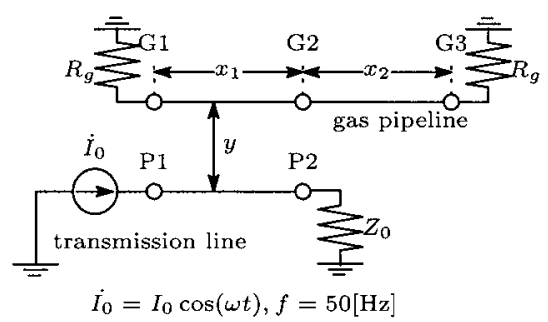

(a) A model circuit

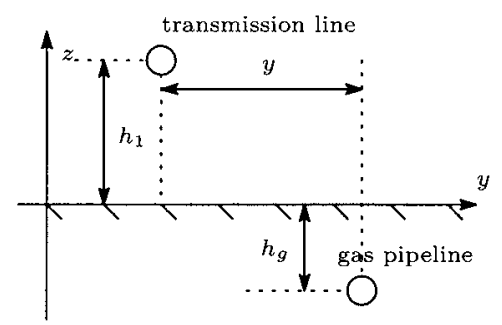

(b) Cross-section

困 4 シミュレーション回路

Fig. 4. A simulation circuit.

表 1 単相線路でのシミュレーション条件

Table 1. Simulaiton conditions on a single-phase line.

\begin{tabular}{|c|c|c|c|c|c|}
\hline case & $x_{1} / x_{2}[\mathrm{~km}]$ & $y[\mathrm{~m}]$ & $I_{0}[\mathrm{~A}]$ & $Z_{m} \angle \theta_{0}[\Omega / \mathrm{km}]$ & $V_{m} \angle \theta_{m}[\mathrm{~V}]$ \\
\hline 11 & $0.5 / 0$ & 500 & $1 \mathrm{k}$ & $0.0431 \angle 41.4^{\circ}$ & $21.5 \angle-138.9^{\circ}$ \\
\hline 12 & $0.5 / 0$ & 1000 & $1 \mathrm{k}$ & $0.0174 \angle 18.4^{\circ}$ & $8.7 \angle-161.6^{\circ}$ \\
\hline 13 & $1.0 / 0$ & 500 & $1 \mathrm{k}$ & $0.0431 \angle 41.4^{\circ}$ & $21.5 \angle-138.9^{\circ}$ \\
\hline 14 & $1.0 / 0$ & 1000 & $1 \mathrm{k}$ & $0.0174 \angle 18.4^{\circ}$ & $17.4 \angle-161.6^{\circ}$ \\
\hline 21 & $0.5 / 2$ & 1000 & $1 \mathrm{k}$ & $0.0174 \angle 18.4^{\circ}$ & $8.7 \angle-161.6^{\circ}$ \\
\hline 22 & $0.5 / 10$ & 1000 & $1 \mathrm{k}$ & $0.0174 \angle 18.4^{\circ}$ & $8.7 \angle-161.6^{\circ}$ \\
\hline 23 & $1.0 / 2$ & 1000 & $1 \mathrm{k}$ & $0.0174 \angle 18.4^{\circ}$ & $17.4 \angle-161.6^{\circ}$ \\
\hline 24 & $1.0 / 10$ & 1000 & $1 \mathrm{k}$ & $0.0174 \angle 18.4^{\circ}$ & $17.4 \angle-161.6^{\circ}$ \\
\hline 31 & $0.5 / 0$ & 500 & 500 & $0.0431 \angle 41.4^{\circ}$ & $10.8 \angle-138.9^{\circ}$ \\
\hline 32 & $0.5 / 0$ & 1000 & 500 & $0.0174 \angle 18.4^{\circ}$ & $4.4 \angle-161.6^{\circ}$ \\
\hline 33 & $1.0 / 0$ & 500 & 500 & $0.0431 \angle 41.4^{\circ}$ & $21.6 \angle-138.9^{\circ}$ \\
\hline 34 & $1.0 / 0$ & 1000 & 500 & $0.0174 \angle 18.4^{\circ}$ & $8.7 \angle-161.6^{\circ}$ \\
\hline
\end{tabular}

る。表 1 に計算条件および送電線とガスパイプラインの相 互インピーダンス $Z_{m}$ および誘導電圧近似解 $V_{m}=-Z_{m} I_{0}$, 表 2 に EMTP 計算結果を示す。

表 2 のシミュレーション結果において, 交流誘導電圧值 は表 1 に示す周知の近似式 $\dot{V}_{m}=-\dot{Z}_{m} \dot{I}_{0}$ にほぼ一致してい ることが知られる。またガスパイプ端子電圧值 $V_{G 1}, V_{G 2}$ も 近似式 $V_{G 1} \simeq V_{G 2} \simeq Z_{m} I_{0} / 2$ を満足している(10)。従って用 いたシミュレーション手法は妥当であると考えられる。

表 2 から, 交流誘導電圧は送電線とガスパイプラインの 離隔距離，並行区間長さおよび送電線電流值により決定さ れることがわかる。これは $\dot{V}_{m}=-\dot{Z}_{m} \dot{I}_{0}$ において $Z_{m}$ が線 路長 $x_{1}$ と共に増加し, 離隔距離と共に減少することからも 明らかである。注目すべきは，ノード G3 の電圧が送電線 との並行区間でのガスパイプ電圧 $V_{G 1}, V_{G 2}$ とほほ同一の 值となること，および $V_{G 3}$ はノード G2-G3 間のガスパイ プ長 $x_{2}$ にあまり依存しないことであろう。過渡現象を考え る際，線路の進行波および反射波により電圧分布が決定さ れる。しかし，定常状態では送電線と並行していない区間
表 2 単相線路でのシミュレーション結果

Table 2. Simulaiton results on a single-phase line.

(a) Lumped-parameter model

\begin{tabular}{|c|c|c|c|c|}
\multicolumn{5}{c|}{ (a) Lumped-parameter model } \\
\hline case & $V_{G 1} \angle \theta_{1}[\mathrm{~V}]$ & $V_{G 2} \angle \theta_{2}[\mathrm{~V}]$ & $V_{G 3} \angle \theta_{3}[\mathrm{~V}]$ & $V_{m} \angle \theta_{m}[\mathrm{~V}]$ \\
\hline 11 & $10.7 \angle 40.6^{\circ}$ & $10.7 \angle-139.4^{\circ}$ & - & $21.4 \angle-139.4^{\circ}$ \\
\hline 12 & $4.33 \angle 17.6^{\circ}$ & $4.33 \angle-162.4^{\circ}$ & - & $8.7 \angle-162.4^{\circ}$ \\
\hline 13 & $21.4 \angle 39.7^{\circ}$ & $21.4 \angle-140.3^{\circ}$ & - & $42.8 \angle-140.3^{\circ}$ \\
\hline 14 & $8.64 \angle 16.7^{\circ}$ & $8.64 \angle-163.3^{\circ}$ & - & $17.3 \angle-163.3^{\circ}$ \\
\hline 21 & $4.27 \angle 15.8^{\circ}$ & $4.40 \angle-160.7^{\circ}$ & $4.28 \angle-167.2^{\circ}$ & $8.7 \angle-162.4^{\circ}$ \\
\hline 22 & $3.89 \angle 10.5^{\circ}$ & $4.82 \angle-156.5^{\circ}$ & $4.05 \angle 174.3^{\circ}$ & $8.7 \angle-162.3^{\circ}$ \\
\hline 23 & $8.51 \angle 15.0^{\circ}$ & $8.77 \angle-161.5^{\circ}$ & $8.53 \angle-168.0^{\circ}$ & $17.3 \angle-163.2^{\circ}$ \\
\hline 24 & $7.73 \angle 9.77^{\circ}$ & $9.61 \angle-157.2^{\circ}$ & $8.06 \angle 173.6^{\circ}$ & $17.2 \angle-163.0^{\circ}$ \\
\hline 31 & $5.37 \angle 40.6^{\circ}$ & $5.37 \angle-139.4^{\circ}$ & - & $10.7 \angle-139.4^{\circ}$ \\
\hline 32 & $2.17 \angle 17.6^{\circ}$ & $2.17 \angle-162.4^{\circ}$ & - & $4.3 \angle-162.4^{\circ}$ \\
\hline 33 & $10.7 \angle 39.7^{\circ}$ & $10.7 \angle-140.3^{\circ}$ & - & $21.4 \angle-140.3^{\circ}$ \\
\hline 34 & $4.32 \angle 16.7^{\circ}$ & $4.32 \angle-163.3^{\circ}$ & - & $8.6 \angle-163.3^{\circ}$ \\
\hline
\end{tabular}

(b) Distributed-parameter model

\begin{tabular}{|c|c|c|c|c|}
\hline case & $V_{G 1} \angle \theta_{1}[\mathrm{~V}]$ & $V_{G 2} \angle \theta_{2}[\mathrm{~V}]$ & $V_{G 3} \angle \theta_{3}[\mathrm{~V}]$ & $V_{m} \angle \theta_{m}[\mathrm{~V}]$ \\
\hline 11 & $10.7 \angle 46.5^{\circ}$ & $10.7 \angle-133.6^{\circ}$ & - & $21.4 \angle-133.6^{\circ}$ \\
\hline 12 & $4.32 \angle 23.5^{\circ}$ & $4.32 \angle-156.6^{\circ}$ & - & $8.6 \angle-156.6^{\circ}$ \\
\hline 13 & $21.3 \angle 45.7^{\circ}$ & $21.4 \angle-134.5^{\circ}$ & - & $42.7 \angle-134.4^{\circ}$ \\
\hline 14 & $8.62 \angle 22.7^{\circ}$ & $8.62 \angle-157.5^{\circ}$ & - & $17.2 \angle-157.4^{\circ}$ \\
\hline 21 & $4.29 \angle 21.7^{\circ}$ & $4.34 \angle-154.8^{\circ}$ & $4.28 \angle-161.4^{\circ}$ & $8.6 \angle-156.5^{\circ}$ \\
\hline 22 & $4.02 \angle 15.6^{\circ}$ & $4.67 \angle-149.6^{\circ}$ & $4.08 \angle 179.7^{\circ}$ & $8.6 \angle-156.4^{\circ}$ \\
\hline 23 & $8.56 \angle 20.9^{\circ}$ & $8.67 \angle-155.7^{\circ}$ & $8.54 \angle-162.3^{\circ}$ & $17.2 \angle-157.4^{\circ}$ \\
\hline 24 & $8.01 \angle 14.8^{\circ}$ & $9.31 \angle-150.4^{\circ}$ & $8.14 \angle 178.9^{\circ}$ & $17.2 \angle-157.2^{\circ}$ \\
\hline 31 & $5.35 \angle 46.5^{\circ}$ & $5.35 \angle-133.6^{\circ}$ & - & $10.7 \angle-133.6^{\circ}$ \\
\hline 32 & $2.16 \angle 23.5^{\circ}$ & $2.16 \angle-156.6^{\circ}$ & - & $4.3 \angle-156.6^{\circ}$ \\
\hline 33 & $10.7 \angle 45.7^{\circ}$ & $10.7 \angle-134.5^{\circ}$ & - & $21.4 \angle-134.4^{\circ}$ \\
\hline 34 & $4.31 \angle 22.7^{\circ}$ & $4.31 \angle-157.5^{\circ}$ & - & $8.6 \angle-157.4^{\circ}$ \\
\hline
\end{tabular}

であるノード G2-G3 間では交流誘導電圧が発生せず，電 気磁気学的に同一導体は同電位となることから, 上記の現 象が説明できる。

さらに, 図 3 に示す分布定数モデルと集中定数モデルを 比較すると, 交流誘導電圧の位相に若干の差異が見られる だけであった。今回行ったシミュレーションは定常状態の シミュレーションであり, 過渡現象ではないため, 集中定数 モデルでも十分な精度を得られると考えられる。なお，以 下の計算では全て分布定数モデルを用いる。

本計算は送電線 1 相のみを考えた場合であり，実際には 3 相, および 2 回線分の各相電流による誘導電圧のベクト ル和になるため, 1 相のみの場合より誘導電圧は小となる。 また, 送電線 1 相のみを対象とした解析は送電線の 1 線地 絡事故に対応するものとして電話線への誘導電圧分野でよ く知られている(9)(10)。

次にガスパイプライン交流誘導電圧分布について考察す る。罒 4(a) に示すような長さ $x[\mathrm{~km}]$ の架空送電線に, 大地 を帰路とする起誘導電流 $I_{0}[\mathrm{~A}]$ が流れたとき，ガスパイプ ラインに誘導する電圧分布を求める。ここでガスパイプラ インのインピーダンス $Z[\Omega / \mathrm{km}]$, アドミタンス $Y[\mathrm{~S} / \mathrm{km}]$ と し, ガスパイプラインと架空電力線との間の相互インピー ダンス $Z_{m}[\Omega / \mathrm{km}]$ とする。架空電力線電流は電力線各点に おいて同相, 同大とし, ガスパイプラインの両端開放とす ると, 架空-地中導体間の相互アドミタンス $Y_{m}$ は通常 0 な 


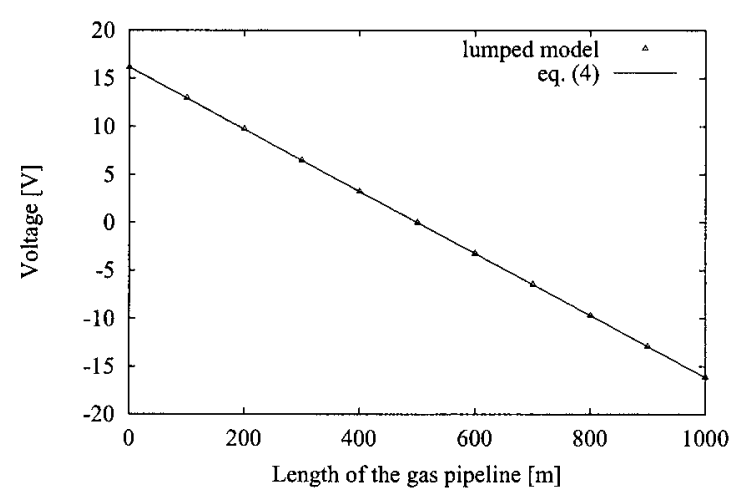

図 5 誘導電圧の分布

Fig. 5. Induced voltge distribution.

ので次式が得られる ${ }^{(11)}$ 。

$$
V=\frac{I_{0} Z_{m}}{\Gamma} \frac{\cosh \Gamma(l-x)-\cosh \Gamma x}{\sinh \Gamma l} .
$$

表 1 case 13 の条件（ただしガスパイプラインの両端は開 放）での線路長 $100[\mathrm{~m}]$ 間隔の誘導電圧シミュレーション 結果と上式による解析結果を図 5 に示す。図よりガスパイ プライン両端での電圧が最も高く，中央での電圧が最も低 くなる結果が得られた。さらに(4) 式の結果とシミュレー ション結果とはほぼ一致している。

〈3.2〉 3 相水平配列線路 図 6(a) に示す $500 \mathrm{kV} 3$ 相 水平配列線路の場合について検討する。ノード P1 に次式 に示す 3 相交流電源を接続する。

$$
\left.\begin{array}{l}
I_{u}=I_{0} \cos \left(\omega t-120^{\circ}\right) \\
I_{v}=I_{0} \cos (\omega t) \\
I_{w}=I_{0} \cos \left(\omega t+120^{\circ}\right) \\
I_{0}=1 \mathrm{kA}, f=50 \mathrm{~Hz}
\end{array}\right\}
$$

ガスパイプラインは図 1 と同一とする。Cable Parameters の計算結果よりこの水平配列線路の自己サージインピーダ ンスは $380 \Omega$ となり，対応する多相整合抵抗を接続した。 なおガスパイプライン接地抵抗 $R_{g}$ は $10 \Omega$ とした。線路長 は送電線とガスパイプラインの並行する区間 $x_{1}=1[\mathrm{~km}]$, ガスパイプラインのみの区間 $x_{2}=0$ である。また図 6 に示 す $y$ は水平配列線路中央の導体からガスパイプラインまで の水平離隔距離であり, 例えば case 11 では $y=-100[\mathrm{~m}]$ としている。

表 3(a) に水平配列線路からガスパイプラインへの交流誘 導電圧シミュレーション結果を示す。表より, case 12 と case 16 (水平離隔距離 $y= \pm 28 \mathrm{~m}$ ) のとき交流誘導電圧が 最大となる結果が得られた。また今回のケースでは $y=0$ （送電線中相の直下）拈よび $y= \pm 100 \mathrm{~m}$ のとき，交流誘導 電圧は最小となった。これは送電線を流れる電流が対称 3 相交流電流であり，各相による磁束が打ち消しあうためと 考えられる。さらに距離 $y$ を無限長とすれば交流誘導電圧 は 0 となる。

表 3(a)の結果について近似式 $V_{m}=-Z_{m} I$ より解析的に

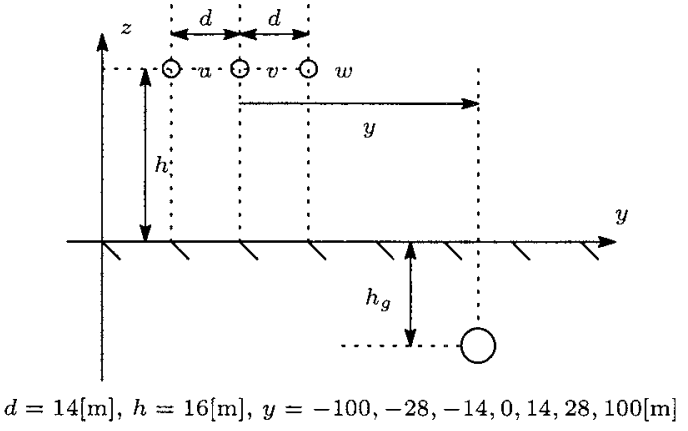

(a) 3-phase horizontal line

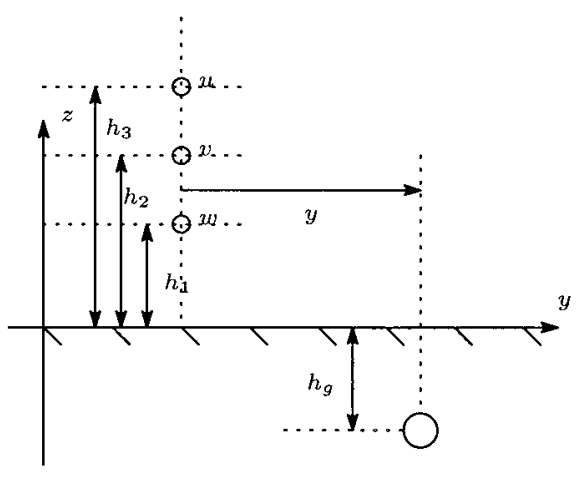

$h_{1}=16[\mathrm{~m}], h_{2}=20[\mathrm{~m}], h_{3}=24[\mathrm{~m}]$

(b) 3-phase vertical line

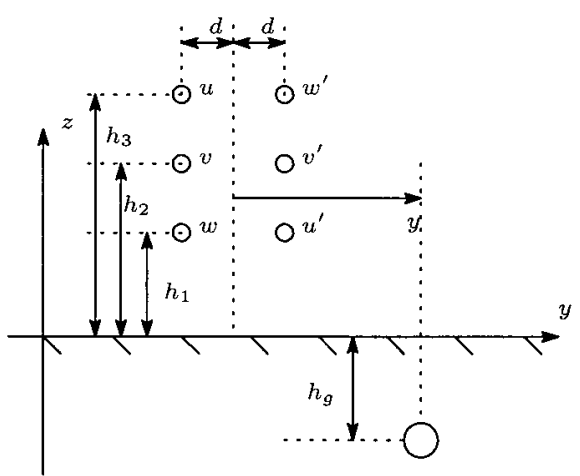

$h_{1}, h_{2}, h_{3}:$ same as (b)

(c) Vertical twin-circuit line

$r_{p}=16.77[\mathrm{~cm}], \rho_{p}=3.18 \times 10^{-8}[\Omega \mathrm{m}], \rho_{e}=50[\Omega \mathrm{m}]$

図 6 線路構造

Fig. 6. Line configuration.

検討する。送電線各相のガスパイプラインに対する相互イ ンピーダンスは次式で与えられる。

$$
\left.\begin{array}{l}
Z_{m u}=0.137 \angle 69.82^{\circ} \\
Z_{m v}=0.128 \angle 68.56^{\circ} \\
Z_{m w}=0.121 \angle 67.35^{\circ} \quad[\Omega / \mathrm{km}]
\end{array}\right\}
$$

(5), (6) 式から各相による誘導電圧は次の結果となる。

$$
\left.\begin{array}{l}
V_{m u}=136.5 \angle 129.8^{\circ} \\
V_{m v}=128.0 \angle-111.4^{\circ} \\
V_{m w}=120.5 \angle 7.35^{\circ} \quad[\mathrm{V} / \mathrm{km}]
\end{array}\right\}
$$

ガスパイプラインの交流誘導電圧は上式のベクトル和とし て次のように与えられる。 
表 3 多相線路でのシミュレーション結果

Table 3. Simulation results on a multiphase line.

(a) Three-phase horizontal line (case 1)

\begin{tabular}{|c|c|l|l|l|}
\hline case & $y[\mathrm{~m}]$ & $V_{G 1} \angle \theta_{1}[\mathrm{~V}]$ & $V_{G 2} \angle \theta_{2}[\mathrm{~V}]$ & $V_{m} \angle \theta_{m}[\mathrm{~V}]$ \\
\hline 11 & -100.0 & $7.29 \angle-5.65^{\circ}$ & $7.29 \angle 174.4^{\circ}$ & $14.6 \angle 174.3^{\circ}$ \\
\hline 12 & -28.0 & $18.5 \angle-4.79^{\circ}$ & $18.5 \angle 175.2^{\circ}$ & $37.0 \angle 175.2^{\circ}$ \\
\hline 13 & -14.0 & $16.3 \angle 5.95^{\circ}$ & $16.3 \angle-174.1^{\circ}$ & $32.6 \angle-174.1^{\circ}$ \\
\hline 14 & 0.0 & $7.09 \angle 88.2^{\circ}$ & $7.09 \angle-91.8^{\circ}$ & $14.2 \angle-91.8^{\circ}$ \\
\hline 15 & 14.0 & $16.3 \angle 170.2^{\circ}$ & $16.3 \angle-9.77^{\circ}$ & $32.6 \angle-9.79^{\circ}$ \\
\hline 16 & 28.0 & $18.4 \angle-179.3^{\circ}$ & $18.4 \angle 0.70^{\circ}$ & $36.8 \angle 0.70^{\circ}$ \\
\hline 17 & 100.0 & $7.25 \angle 178.2^{\circ}$ & $7.25 \angle-1.77^{\circ}$ & $14.5 \angle-1.79^{\circ}$ \\
\hline
\end{tabular}

(b) Three-phase vertical line (case 2)

\begin{tabular}{|c|c|l|l|l|}
\hline case & $y[\mathrm{~m}]$ & $V_{G 1} \angle \theta_{1}[\mathrm{~V}]$ & $V_{G 2} \angle \theta_{2}[\mathrm{~V}]$ & $V_{m} \angle \theta_{m}[\mathrm{~V}]$ \\
\hline 21 & -100.0 & $0.17 \angle 108.4^{\circ}$ & $0.16 \angle-53.7^{\circ}$ & $0.33 \angle-62.9^{\circ}$ \\
\hline 22 & -28.0 & $2.37 \angle-179.5^{\circ}$ & $2.40 \angle 1.21^{\circ}$ & $4.77 \angle 0.9^{\circ}$ \\
\hline 23 & -14.0 & $5.05 \angle 179.0^{\circ}$ & $5.74 \angle 3.59^{\circ}$ & $10.7 \angle 1.4^{\circ}$ \\
\hline 24 & 0.0 & $8.59 \angle 174.4^{\circ}$ & $9.47 \angle 5.32^{\circ}$ & $17.9 \angle 0.1^{\circ}$ \\
\hline 25 & 14.0 & $5.05 \angle 179.0^{\circ}$ & $5.74 \angle 3.59^{\circ}$ & $10.7 \angle 1.4^{\circ}$ \\
\hline 26 & 28.0 & $2.37 \angle-179.5^{\circ}$ & $2.40 \angle 1.21^{\circ}$ & $4.77 \angle 0.9^{\circ}$ \\
\hline 27 & 100.0 & $0.16 \angle 108.4^{\circ}$ & $0.16 \angle-53.7^{\circ}$ & $0.32 \angle-62.7^{\circ}$ \\
\hline
\end{tabular}

(c) Vertical twin-circuit line (case 3)

\begin{tabular}{|c|c|l|l|l|}
\hline case & $y[\mathrm{~m}]$ & $V_{G 1} \angle \theta_{1}[\mathrm{~V}]$ & $V_{G 2} \angle \theta_{2}[\mathrm{~V}]$ & $V_{m} \angle \theta_{m}[\mathrm{~V}]$ \\
\hline 31 & -100.0 & $1.52 \angle-158.1^{\circ}$ & $1.29 \angle-155.8^{\circ}$ & $0.24 \angle 9.3^{\circ}$ \\
\hline 32 & -28.0 & $4.18 \angle-176.2^{\circ}$ & $4.22 \angle 3.95^{\circ}$ & $8.40 \angle 3.9^{\circ}$ \\
\hline 33 & -14.0 & $5.90 \angle-175.4^{\circ}$ & $7.30 \angle-2.55^{\circ}$ & $13.1 \angle 0.6^{\circ}$ \\
\hline 34 & 0.0 & $3.16 \angle 116.1^{\circ}$ & $3.07 \angle 118.6^{\circ}$ & $0.16 \angle-119.1^{\circ}$ \\
\hline 35 & 14.0 & $6.67 \angle 6.37^{\circ}$ & $6.55 \angle-171.4^{\circ}$ & $13.2 \angle-172.5^{\circ}$ \\
\hline 36 & 28.0 & $4.28 \angle 3.59^{\circ}$ & $4.18 \angle-175.3^{\circ}$ & $8.46 \angle-175.9^{\circ}$ \\
\hline 37 & 100.0 & $1.41 \angle 13.8^{\circ}$ & $1.17 \angle 21.2^{\circ}$ & $0.29 \angle 162.7^{\circ}$ \\
\hline \multicolumn{5}{|r}{} \\
\hline
\end{tabular}

$$
V_{m}=V_{m u}+V_{m v}+V_{m w}
$$$$
=14.6 \angle 175.5^{\circ} \quad[\mathrm{V} / \mathrm{km}]
$$

上記計算結果は表 3(a) のケース 11 とよく一致している。 また $V_{m i}$ と $V_{m}$ を比較することで 3 相架空電力線による磁 束はべクトルの和となるため, 交流誘導電圧は単相電力線 よりも 3 相電力線の方が小となることが説明できる。

$\langle\mathbf{3} \cdot \mathbf{3}\rangle \quad 3$ 相垂直配列線路 表 3 (b) に 3 相垂直配列線 路 case 21-27 のシミュレーション結果を示す。表より垂 直配列線路での交流誘導電圧は水平配列線路の半分以下と なることがわかる。また送電線直下 $(y=0)$ での交流誘 導電圧が最大となった。この現象は 3 相送電線の垂直配列 構造よるものであり, 相互インピーダンスから容易に説明 できる。例えば，ガスパイプラインと送電線の離隔距離が $y=-100[\mathrm{~m}]$ の場合,

$$
\begin{aligned}
& Z_{m u}=0.128 \angle 68.61^{\circ} \\
& Z_{m v}=0.128 \angle 68.55^{\circ} \\
& Z_{m w}=0.128 \angle 68.48^{\circ} \quad[\Omega / \mathrm{km}]
\end{aligned}
$$

(5) 式と上式より次の交流誘導電圧が解析的に得られる。

$$
\left.\begin{array}{l}
V_{m u}=127.8 \angle 128.6^{\circ} \\
V_{m v}=128.0 \angle-111.5^{\circ} \\
V_{m w}=128.1 \angle 8.48^{\circ} \\
V_{m}=0.38 \angle-68.7^{\circ} \quad[\mathrm{V} / \mathrm{km}]
\end{array}\right\}
$$

この解析計算結果は表 3(b) のケース 21 のシミュレーショ ン結果とよく一致している。

$\langle$ 3.4〉 3 相 2 回線表 3(c) に case 31-37（3 相 2 回 線線路）のシミュレーション結果を示す。この場合，各相 電流は次式となる。

$$
\left.\begin{array}{l}
I_{u}=I_{u^{\prime}}=I_{0} \cos \left(\omega t-120^{\circ}\right) \\
I_{v}=I_{v^{\prime}}=I_{0} \cos (\omega t) \\
I_{w}=I_{w^{\prime}}=I_{0} \cos \left(\omega t+120^{\circ}\right)
\end{array}\right\}
$$

$500 \mathrm{kV}$ 送電線は通常逆相配列となっているため, 交流誘 導電圧は 3 相 1 回線のケースよりも小となり, かつ, $y=0$ のとき最小となる。

参考迄に $y=-28 \mathrm{~m}$ (case 32) の時の相互インピーダン スと交流誘導電圧の解析計算結果を次に示す。

$$
\left.\begin{array}{l}
Z_{m u}=0.212 \angle 76.94^{\circ} \\
Z_{m v}=0.218 \angle 77.25^{\circ} \\
Z_{m w}=0.225 \angle 77.55^{\circ} \\
Z_{m u^{\prime}}=0.174 \angle 74.11^{\circ} \\
Z_{m v^{\prime}}=0.176 \angle 74.17^{\circ} \\
Z_{m \omega^{\prime}}=0.177 \angle 74.22^{\circ} \quad[\Omega / \mathrm{km}] \\
V_{m u}=212.3 \angle 136.9^{\circ} \\
V_{m v}=218.3 \angle-102.8^{\circ} \\
V_{m w}=224.6 \angle 17.6^{\circ} \\
V_{m u^{\prime}}=174.2 \angle 14.1^{\circ} \\
V_{m v^{\prime}}=175.7 \angle-105.8^{\circ} \\
V_{m \omega^{\prime}}=177.0 \angle 134.2^{\circ} \\
V_{m}=8.51 \angle 0.074^{\circ} \quad[\mathrm{V} / \mathrm{km}]
\end{array}\right\}
$$

\section{4. 実系統でのシミュレーション}

実系統を模擬したモデル系統での誘導電圧シミュレーショ ンを行う。図 7 に系統構成を示す。

ガスパイプ構造は図 1 と同じである。ガスパイプライン は GP00〜 GP13の 13 区間からなり，その一部は送電線と 並行している。図中 $\mathrm{A}$ は $66 \mathrm{kV}, \mathrm{B}$ は $500 \mathrm{kV}$ 送電線であ る。ノード GP02 GP10 の区間は $500 \mathrm{kV}$ 送電線と並行し ている区間とし, GP11〜 GP12 は $66 \mathrm{kV}$ 送電線と並行して いる区間とみなす。

送電線は 3 相非撚架垂直配列 2 回線であり，その線路定 数を表 4 に示す。なお，線路構造は図 6(c) と同様である。 架空電力線とガスパイプラインが斜行しているときには, 始端での離隔距離 $y_{i}$, 終端での離隔距離 $y_{j}$ として,

$$
\begin{aligned}
& y \simeq \sqrt{y_{i} \cdot y_{j}} \cdots \ldots \ldots \ldots \ldots \ldots \ldots \ldots \ldots \ldots \ldots \ldots \\
& \text { ただし } y_{i}=0 \text { のときには } y \simeq 4.68 \sqrt{y_{j}}
\end{aligned}
$$

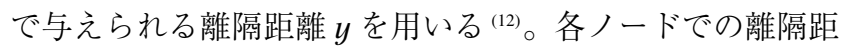
離を表 5 に示す。

電流源は (11) 式と同じである。ただし振幅 $I_{0}$ は電力会社 のデータに従い $66 \mathrm{kV}$ では 120 [A]，500kVでは 1000 [A] 


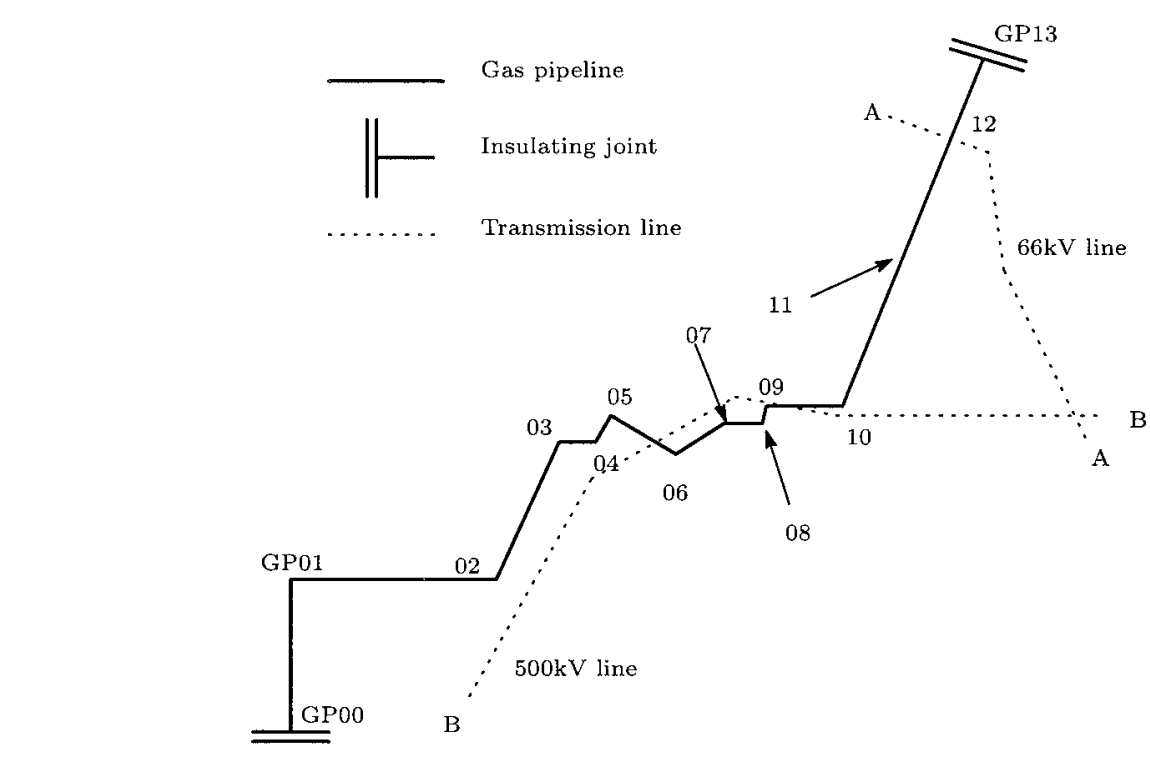

(a) Circuit diagram

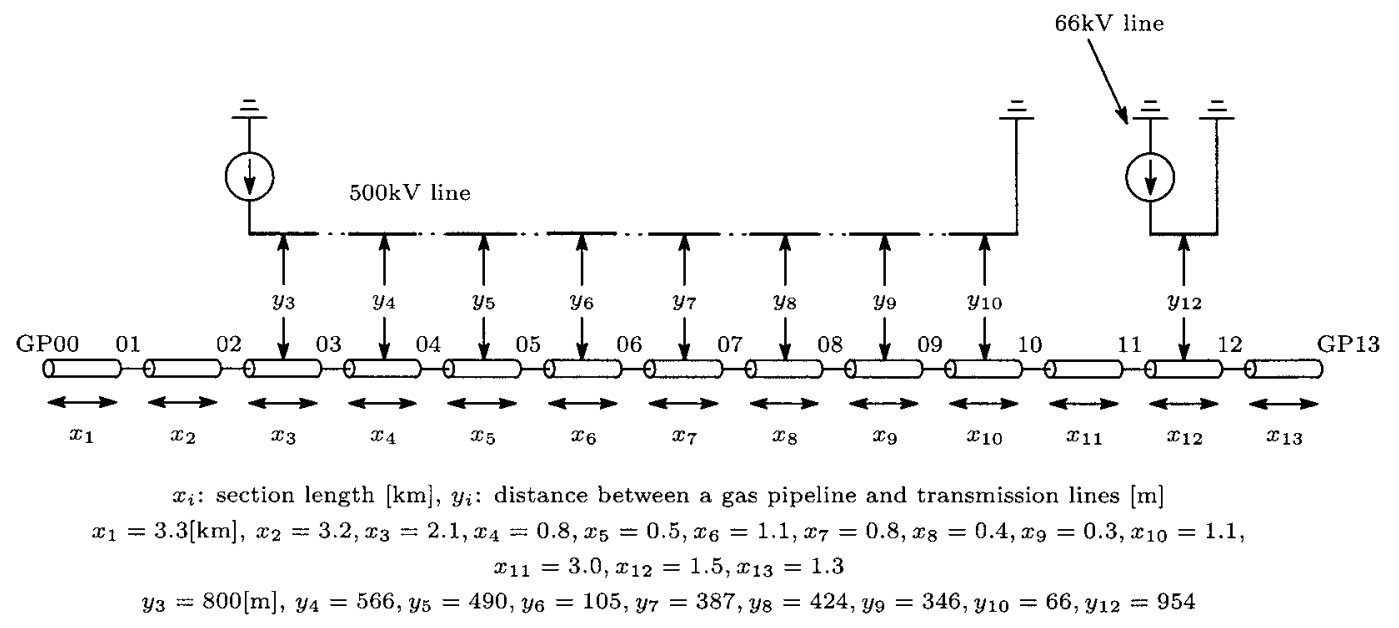

(b) Circuit configuration

図 7 系統構成

Fig. 7. System configuration.

とした。また架空地線の始端及び終端は接地とした。誘導 電圧に対するガスパイプライン接地の影響を検討するため に，ガスパイプ両端のみを $10[\Omega]$ で接地する場合（case 0) と，ガスパイプ各ノードを $10[\Omega]$ で接地する場合 (case 1) のシミュレーションを分布定数線路モデルを用いて行った。

シミュレーション結果を図 8 に示す。図より全てのノー ドに扔いて接地数の多い case 1 の方がガスパイプ交流誘導 電圧が小となる結果となった。また case 0,1 共にガスパイ プの電圧は両端に近いノードが大となり, 中央部の電圧は小 となる傾向が得られた。この電圧分布の特性はく $3 \cdot 1$ 節で検 討した単相線路の結果と同じである。図 8 に执いてもノード GP06〜GP09 では送電線とガスパイプの離隔距離が小にも かかわらず, 交流誘導電圧は小となっている。しかし case 0 に执いてはノード GP09 と GP10 の電位差が最大となって 抢り，ガスパイプと送電線が最も接近していることが原因 と考えられる。ノード GP09-GP10 間での送電線 u 相とガ
スパイプの相互インピーダンスは $46.4+j 135.09[\mathrm{~m} \Omega / \mathrm{km}]$ であり，他のノード間の相互インピーダンスに比べて大で あることからノード GP09-GP10 間の電位差が大となると 推測される。一方, case 1 の場合ノード GP09-GP10 間の 電位差は case 0 に比べて小となっているものの，ノード GP10-GP11 間の電位差は case 0 に比べて大となった。ま た GP11-GP12 間ではガスパイプと $66 \mathrm{kV}$ 送電線の相互イ ンピーダンスは大きくないものの線路長が長いため, 結果 としてノード GP10に影響を与えていると考えられる。

以上のシミュレーションでは大地抵抗率 $\rho_{e}=50[\Omega \mathrm{m}]$ 一定としたが，大地抵抗率を $\rho_{e}=20,50,100[\Omega \mathrm{m}]$ と変化 させた場合のシミュレーション結果を図 9 に示す。図より ノード GP10を除いて大地抵抗率 $\rho_{e}$ が大となるにつれてガ スパイプライン交流誘導電圧も大となることが知られる。

したがってガスパイプライン交流誘導電圧は湿地等の大 地抵抗率が小となる場所では大地の影響により減少するが, 


\section{表 4 線路定数}

Table 4. Line parameters.

\begin{tabular}{|c|c|c|}
\hline system voltage [kV] & 66 & 500 \\
\hline height $h_{g}[\mathrm{~m}]$ & 27 & 39 \\
\hline$h_{3}$ & 23 & 31 \\
\hline$h_{2}$ & 19 & 23 \\
\hline$h_{1}$ & 15 & 15 \\
\hline distance $d[\mathrm{~m}]$ & 5 & 7 \\
\hline \multicolumn{3}{|c|}{ phase conductor } \\
\hline bundle number & 1 & 4 \\
\hline separations $[\mathrm{m}]$ & - & 0.4 \\
\hline inner radius $r_{p i}[\mathrm{~mm}]$ & 5.7 & 1.974 \\
\hline outer radius $r_{p o}[\mathrm{~mm}]$ & 17.1 & 8.74 \\
\hline dc resistance $R_{d c p}[\Omega / \mathrm{km}]$ & 0.0474 & 0.0415 \\
\hline \multicolumn{3}{|c|}{ ground wire } \\
\hline bundle number & 1 & 2 \\
\hline radius $r_{g}[\mathrm{~mm}]$ & 5.25 & 6.18 \\
\hline dc resistance $R_{d c g}[\Omega / \mathrm{km}]$ & 1.270 & 0.4467 \\
\hline
\end{tabular}

表 5 送電線ーガスパイプライン間隔

Table 5. Separation between transimission and gas-pipe lines.

\begin{tabular}{|c|c|c|c|c|}
\hline send. & rec. & $y_{i}[\mathrm{~m}]$ & $y_{j}[\mathrm{~m}]$ & $y[\mathrm{~m}]$ \\
\hline GP02 & GP03 & 800 & 800 & 800 \\
\hline GP03 & GP04 & 800 & 400 & 566 \\
\hline GP04 & GP05 & 400 & 600 & 490 \\
\hline GP05 & GP06 & 500 & 0 & 105 \\
\hline GP06 & GP07 & 500 & 300 & 387 \\
\hline GP07 & GP08 & 300 & 600 & 424 \\
\hline GP08 & GP09 & 600 & 200 & 346 \\
\hline GP09 & GP10 & 200 & 0 & 66 \\
\hline GP11 & GP12 & 1300 & 700 & 954 \\
\hline
\end{tabular}

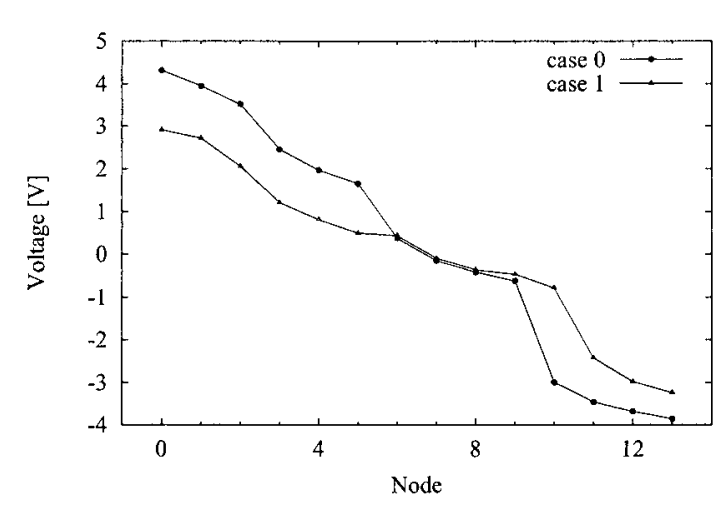

図 8 シミュレーション結果

Fig. 8. Simulation results.

乾燥地等の大地抵抗率が大となる場所では交流誘導電圧も 大となるため，接地数を増やすなどの対策が必要となると 考えられる。

さて，図７に対応する実系統でのガスパイプラインの対 地電圧測定結果は 1.17〜2.48 [V] の範囲にあり, 実測系で の線路構造，電流および大地抵抗率等が明暸ではなかった ことを考慮すると，図 8, 図 9 のシミュレーション結果は

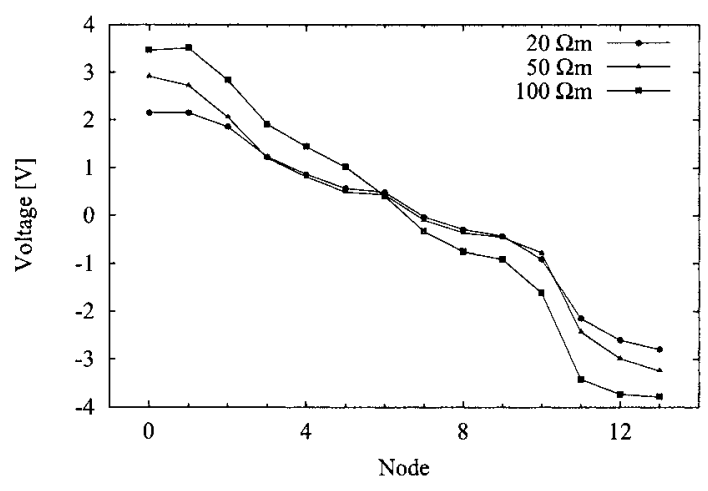

図 9 大地抵抗率の影響

Fig. 9. Effect of earth resistivity.

測定結果にほほ対応していると言える。

\section{5. 結言}

本論文では, 架空電力線から地中埋設ガスパイプライン への交流誘導電圧のシミュレーション手法を確立し, これ による EMTP シミュレーション結果は周知の電磁誘導理論 解と良好に一致すること, また, 実系統での測定結果を概 略再現できることを示した。このシミュレーション手法を 用いて電力線構造の影響について検討し, 以下の事項を明 らかにした。

（1） ガスパイプラインへの交流誘導電圧は電力線を単 相とした場合に最大となる。これは電力線から電話線への 電磁誘導と同じであり, 単相模擬は電力線の地絡事故時に 対応している。

（2） 3 相線路の場合，ガスパイプラインへの誘導電圧 は線路構造および回線数に大きく依存する。誘導電圧は 3 相水平配列線路の場合もっとも大となり, 垂直配列線路の 2 倍程度である。垂直配列の場合, 2 回線では 1 回線に対 して約 $20 \%$ 程度小となる。当然のことながら交流誘導電圧 はガスパイプラインと架空電力線の離隔距離に依存する。

（3）実系統を模擬したシミュレーションではガスパイ プラインをいくつかの区間に分割し，これらを組み合わせ ることでガスパイプライン交流誘導電圧シミュレーション が可能である。

(平成 17 年 4 月 11 日受付, 平成 17 年 7 月 25 日再受付)

$$
\text { 文献 }
$$

(1) Handbook of Corrosions and the Countermeasures, Maruzen (2000) (in Japanese)

腐食・防食ハンドブック, 丸善 出版事業部 (2000)

(2) A. Ametani, J. Kamba, and Y. Hosokawa: "A simulation method of voltages and currents on a gas pipeline and its fault location", IEEJ Trans. PE, Vol.B-123, No.10, pp.1194-1200 (2003-10) (in Japanese)

雨谷昭弘・神波淳介・細川裕司：「ガスパイプラインの電圧・電流 シミュレーション手法と事故評定」, 電学論 B, 123, 10, pp.1194-1200 (2003-10)

(3) W. Scott-Meyer: ATP Rule Book, Bonneville Power Administration (1994)

(4) A. Ametani: Cable Parameters Rule Book, B.P.A. (1996-4)

(5) F. Pollaczek: Über das Feld einer unendlich langen wechsel stromdurchfossenen Einfachleitung, E.N.T., Band 3 (Heft9), pp.339-360 (1926) 
(6) A. Ametani, S. Yamaguchi, and N. Nagaoka: "Mutual Impedance between Overhead and Underground Cables", EMTP J., Vol.4, pp.84-91 (1999)

(7) H. Isogai, A. Ametani, and Y. Hosokawa: "A simulation method of an ac induced voltage on a buried gas pipeline from an overhead line", $2004 \mathrm{Na}-$ tional Convention Record, IEE Japan, No.6-118 (2004-3) (in Japanese) 磯貝 浩・雨谷昭弘・細川裕司：「架空線から地中ガスパイプへの 交流誘導電圧シミュレーション手法」, 平成 16 年電気学会全国大会, No.6-118 (2004-3)

(8) H. Isogai, A. Ametani, and Y. Hosokawa: "Basic Investigation of Induced Voltages to a Buried Gas Pipeline from an Overhead Transmission Line", ICEE'04 Cnference Proceedings, Vol.2, pp.361-365 (2004-7)

(9) A. Ametani: Distributed-Parameter Circuit Theory, Corona Pub. Co. (1990) (in Japanese)

雨谷昭弘：分布定数回路論, コロナ社 (1990)

(10) A. Ametani, M. Aoki, and T. Imamura: "Basic investigation of transient voltage and current to a communication wire from an overhead transmission line", T. IEE Japan, Vol.B-109, No.4, pp.153-160 (1989-4) (in Japanese) 雨谷昭弘・青木眞弓 · 今村隆司 : 「架空送電線から通信線への過渡誘 導電圧・電流の基礎的研究」, 電学論 B, 109, 4, pp.153-160 (1989-4)

(11) T. Koike: Transmission and Distribution Engineering, Cap.9.5, Yokendo Pub. Co. (1995) (in Japanese)

小池東一郎：送配電工学 (前編), 9.5 節, 養賢堂 (1995)

(12) A. Ametani, K. Kaneko, and H. Tsujimura: Electric Energy Sysytem Engineering, Cap.2.6, Nikkan-Kogyo Press (1988) (in Japanese)

雨谷昭弘・金子和博・辻村 寛: 電気エネルギーシステム工学, 2.6 節, 日刊工業新聞社 (1988)
磯 貝 浩 (学生員) 1980 年 9 月 25 日生。 2003 年 3 月同

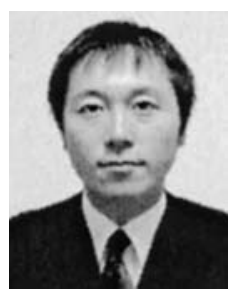
志社大学工学部電気工学科卒業。2005 年同大学 大学院工学研究科電気工学専攻修士課程修了。同 年 4 月東京電力 (株) 入社，現在に至る。

雨 谷 昭 弘 (正員) 1944 年 2 月 14 日生。 1968 年 3 月同志社

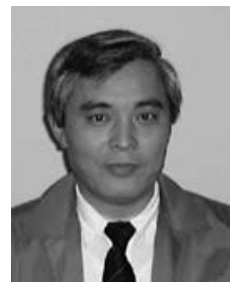
大学大学院電気工学専攻修士課程修了。1973 年マ ンチェスタ大学院博士課程修了，Ph.D.。1976 年 から 1981 年米国エネルギー省にて EMTP の開発 に従事。1985 年同志社大学教授。1988 年 Leuven 大学教授兼任。1996 1997 年同志社大学理工学 研究所所長。1998 2001 年同大学学術情報セン 夕一所長。2003 2004 年電気学会理事副会長。分 布定数回路, 過渡現象, 高調波, 数值解析法の開発に従事。1976 年電 気学会論文賞。1996 年照明学会論文賞。英国技術士。CIGRE 特別会 員。IEE および IEEE フェロー。

細 川 裕 司 (非会員) 1971 年 3 月 28 日生。1995 年 3 月東

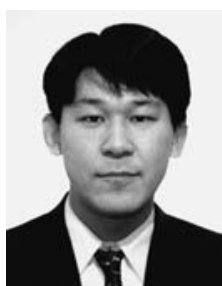
京大学大学院工学研究科修士課程修了。同 4 月東 大学)。ガスパイプラインの電気防食, 塗覆装損 傷検知等の開発・研究に従事。 京ガス (株) 入社。2004 年 4 月工学博士（東京 